Sensational Internationalism 
Edinburgh Critical Studies in Atlantic Literatures and Cultures Edited by Andrew Taylor, Colleen Glenney Boggs and Laura Doyle Available titles

Sensational Internationalism: The Paris Commune and the Remapping of American Memory in the Long Nineteenth Century

J. Michelle Coghlan

Forthcoming titles

Emily Dickinson and Her British Contemporaries: Victorian Poetry in Nineteenth-Century America

Páraic Finnerty

Following the Middle Passage: Currents in Literature Since 1945 Carl Plasa

Visit the series website at: edinburghuniversitypress.com/seriesedinburgh-critical-studies-in-atlantic-literatures-and-cultures.html 


\section{Sensational Internationalism}

The Paris Commune and the Remapping of American Memory in the Long

Nineteenth Century

J. Michelle Coghlan 
Edinburgh University Press is one of the leading university presses in the UK. We publish academic books and journals in our selected subject areas across the humanities and social sciences, combining cutting-edge scholarship with high editorial and production values to produce academic works of lasting importance. For more information visit our website: edinburghuniversitypress.com

(C) J. Michelle Coghlan, 2016

Edinburgh University Press Ltd

The Tun - Holyrood Road, 12(2f) Jackson's Entry, Edinburgh EH8 8PJ

Typeset in II/I3 Adobe Sabon by IDSUK (DataConnection) Ltd, and printed and bound in Great Britain by CPI Group (UK) Ltd, Croydon CR0 4YY

A CIP record for this book is available from the British Library

ISBN 9781474411202 (hardback)

ISBN 9781474411219 (webready PDF)

ISBN 9781474411226 (epub)

The right of J. Michelle Coghlan to be identified as the author of this work has been asserted in accordance with the Copyright, Designs and Patents Act 1988, and the Copyright and Related Rights Regulations 2003 (SI No. 2498). 